\title{
Significance of biomass and light availability to phytoplankton productivity in San Francisco Bay
}

\author{
Brian E. Cole and James E. Cloern \\ US Geological Survey, 345 Middlefield Road, MS 96, Menlo Park, California 94025, USA
}

\begin{abstract}
Primary productivity was measured monthly at 6 sites within San Francisco Bay, USA, throughout 1980. The 6 sites were chosen to represent a range of estuarine environments with respect to salinity, phytoplankton community composition, turbidity, and water depth. Annual net production over the photic zone ranged from 95 to $150 \mathrm{~g} \mathrm{C} \mathrm{m}^{-2}$, and was highest in regions of lowest turbidity. Daily photic zone net productivity $\mathrm{PN}_{\mathrm{pd}}$ ranged from 0.05 to $2.2 \mathrm{~g} \mathrm{C} \mathrm{m}^{-2} \mathrm{~d}^{-1}$, and was significantly correlated with the composite parameter $\mathrm{B}_{\mathrm{o}} / \varepsilon$ (where $\mathrm{B}=$ phytoplankton biomass; $\mathrm{I}_{\mathrm{o}}=$ daily surface insolation; $\varepsilon=$ attenuation coefficient). Linear regression of $\mathrm{PN}_{\mathrm{pd}}$ against $\mathrm{B} \mathrm{I}_{\mathrm{o}} / \varepsilon$ indicated that most $(82 \%)$ of the spatio-temporal variability in primary productivity within this estuary is explained by variations in light availability and phytoplankton biomass. We also calculated annual water-column net productivity $\mathrm{PN}_{w y}$ as a fraction of annual gross productivity $\mathrm{PG}_{\mathrm{Y}}$. The ratio $\mathrm{PN}_{w y}$ : $\mathrm{PG}_{\mathrm{Y}}$ was inversely related to the ratio of water depth $\mathrm{H}$ to annual mean photic depth $\mathrm{Z}_{\mathrm{p}}$. This linear relation indicates that the water column of San Francisco Bay is a net photosynthetic source of organic carbon only when the ratio $H: \bar{Z}_{p}<6$. In deep turbid habitats, where $H: \bar{Z}_{p}>6$, respiratory loss exceeds productivity. Thus, 2 empirical formulations allow us to estimate productivity over the photic zone and water column from simple properties that are easily measured.
\end{abstract}

\section{INTRODUCTION}

Estimates of annual phytoplankton productivity in estuaries range between $6.8 \mathrm{~g} \mathrm{C} \mathrm{m}^{-2}$ (Joint and Pomroy, 1981) in very turbid water to $530 \mathrm{~g} \mathrm{C} \mathrm{m}^{-2}$ (Stockner and Cliff, 1979) in a clearer system. However, the study of production by estuarine phytoplankton is in its infancy, and although annual rates of phytoplankton production have been reported for a number of estuaries (Boynton et al., 1982), the processes that control primary and secondary productivity in estuaries are poorly understood. In a review of factors controlling phytoplankton production in 63 estuarine systems, Boynton et al. (1982) note that environmental data are poor predictors of primary productivity. They conclude that in a broad spectrum of estuaries algal production is high in warm periods and that the ratio of nitrogen to phosphorus is low during algal blooms. Otherwise, they find that generalities regarding primary productivity cannot be made when all estuarine systems are considered together.

Spatial and seasonal changes in phytoplankton productivity are described for numerous estuaries (e.g. Williams, 1966; Williams and Murdoch, 1966; Flemer,
1970; Cadée and Hegeman, 1974; Malone, 1977; Cadée, 1978; Colijn, 1978; Stockner and Cliff, 1979; Stockner et al., 1979; Joint and Pomroy, 1981). From such studies we know that productivity in a nutrient replete estuary can vary with phytoplankton biomass, turbidity, daylength, or temperature, but the findings from specific locations cannot be easily related to other estuarine systems. Except for Boynton et al. (1982), there has been little effort in developing a unified theory of what factors control primary productivity in diverse estuarine systems. In simplest terms, primary productivity in nutrient-rich waters is a function of 3 basic variables: phytoplankton biomass, biomassspecific carbon assimilation rate, and light availability. Although these may vary due to changes in phytoplankton community composition, light adaptation, grazing, settling, transport processes, temperature, daylength, or turbulence, if appropriately expressed, productivity should be predictable in terms of the 3 basic variables.

In this paper we present the results of an annual study of phytoplankton production in San Francisco Bay, USA. We show that seasonal variations in productivity differ among geographic regions within the estu- 
ary, but that daily net productivity in the photic zone is highly correlated with a simple composite parameter composed of phytoplankton biomass and light availability. We also show that the concept of critical depth : mixed depth ratio, which has become a paradigm of phytoplankton ecology in oceans and lakes (Parsons and Takahashi, 1973; Harris, 1978), has relevance to turbid estuaries such as San Francisco Bay. Using the water depth : photic depth ratio we predict the fraction of gross primary production that is lost to respiration and the fraction that remains for potential consumption by herbivores.

San Francisco Bay (Fig. 1) offers a variety of subenvironments for studying the regulation of primary pro-

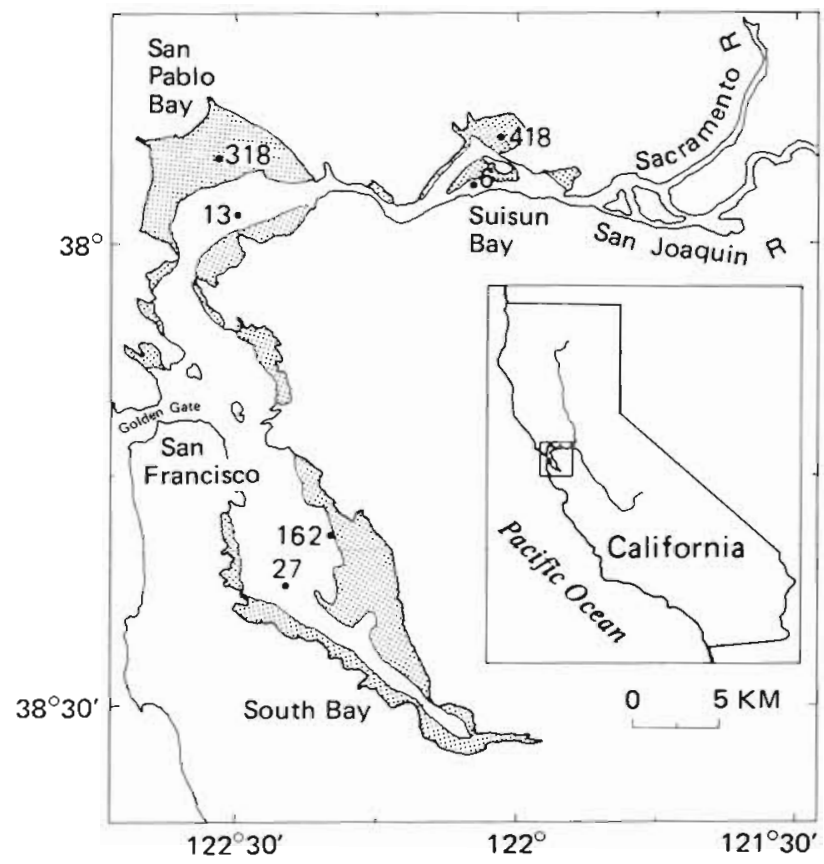

Fig. 1. Map of San Francisco Bay showing locations of incubation sampling sites. Shaded portions: areas where water depths (MLLW) are less than $2 \mathrm{~m}$

duction in nutrient-rich, turbid waters. The northern reach, which includes San Pablo Bay and Suisun Bay, is a river-dominated estuary. It is partially or well mixed (depending on discharge from the Sacramento and San Joaquin Rivers), turbid, and characterized by a large horizontal salinity gradient. In contrast, the southern reach (South Bay) is a brackish embayment that has no large direct riverine source of freshwater, is usually vertically mixed (although salinity stratification occurs in winter-spring; Cloern, 1984), is less turbid than the northern reach, and usually has a small horizontal salinity gradient. Detailed descriptions of the hydrographic, nutrient, and biological character of the San Francisco Bay system are given in Conomos
(1979). Each major embayment (South Bay, San Pablo Bay, Suisun Bay) is composed of a central, relatively deep ( $=10$ to $15 \mathrm{~m}$ ) channel where the photic zone is about $10 \%$ of the water depth, bounded by broad expanses of shoals $(\simeq 2 \mathrm{~m}$ depth) where the photic zone is 50 to $100 \%$ of water depth. Typically, nutrient levels throughout the Bay exceed $10 \mu \mathrm{M}$ dissolved inorganic nitrogen, $2 \mu \mathrm{M}$ phosphate, and $50 \mu \mathrm{M}$ silicate (Conomos et al., 1979). Phytoplankton community composition differs in the three major embayments. The South Bay population is usually dominated by microflagellates (<15 $\mu \mathrm{m}$ length) and small $(<10 \mu \mathrm{m}$ diameter) centric diatoms, although Skeletonema costatum and larger (> $70 \mu \mathrm{m}$ diameter) diatoms Thalassiosira spp. and Coscinodiscus spp. are occasionally abundant. In San Pablo Bay the population comprises marine-brackish diatoms and microflagellates, whereas in Suisun Bay freshwater diatoms usually predominate in winter and $S$. costatum and $T$. eccentrica are dominant during the summer bloom (Wong and Cloern, 1982).

\section{METHODS}

Between January 1980 and February 1981 light attenuation, chlorophyll $a$, and phytoplankton production were measured monthly at a deep-water and shallow-water site in each of the 3 major embayments in San Francisco Bay (Fig. 1). Light attenuation coefficient $\varepsilon$ (all symbols and units are given in Table 1) was measured using a LiCor model 185 quantum meter coupled to a $192 \mathrm{~S}$ sensor. Total ambient insolation $I_{\circ}$ (photosynthetically active radiation) during the course of an incubation experiment was measured using a LiCor 190 quantum sensor and a recording integrator. Photic depth $Z_{p}$ (depth of $1 \%$ ambient light energy) was estimated as $\ln (100) / \varepsilon$.

Triplicate chlorophyll a samples from each site were prescreened through $59 \mu \mathrm{m}$ Nitex screen (see below), then filtered onto Gelman type A/E glass-fiber filters. Chlorophyll a concentration B, corrected for phaeopigments, was determined by fluorometry (Strickland and Parsons, 1972). Although prescreening with a $59 \mu \mathrm{m}$ mesh may remove large algal cells or chains, there was never a measurable difference in in vivo fluorescence between whole and screened samples, except at Station 318 on May 8 and at Stations 13 and 318 on June 5.

Productivity samples were collected from a single depth, $2 \mathrm{~m}$ in the channel and $1 \mathrm{~m}$ in the shoals, and also prescreened through a $59 \mu \mathrm{m}$ Nitex screen. The small mesh was used to eliminate grazing by copepod nauplii and tintinnid ciliates which at times constituted a substantial fraction of zooplankton biomass (Hutchinson, 1981; 1982a, b). Following inoculation with carbon 14 (5 $\mu \mathrm{Ci}$ in a $150 \mathrm{ml}$ bottle), $24 \mathrm{~h}$ simu- 
Table 1. Definitions of variables (and their units)

\begin{tabular}{|c|c|c|}
\hline Variable & Definition & Units \\
\hline$\varepsilon$ & Light attenuation coefficient & $\mathrm{m}^{-1}$ \\
\hline$I_{0}$ & Ambient photosynthetically active radiation & Einsteins $\left(m^{2} d\right)^{-1}$ \\
\hline$z_{p}$ & Photic-zone depth & $\mathrm{m}$ \\
\hline $\mathrm{B}$ & Chlorophyll a concentration & $\mathrm{mg}$ chl a $\mathrm{m}^{-3}$ \\
\hline $\mathrm{P}_{\mathrm{m}}^{\mathrm{B}}$ & Maximum carbon assimilation rate & $\mathrm{mg} C(\mathrm{mg} \operatorname{chl} a \mathrm{~d})^{-1}$ \\
\hline $\mathrm{PN}_{\mathrm{pd}}$ & Daily photic zone net productivity & $g \subset\left(m^{2} d\right)^{-1}$ \\
\hline $\mathrm{PN}_{\mathrm{PY}}$ & Annual photic zone net productivity & $\mathrm{gCC}\left(\mathrm{m}^{2} \mathrm{yr}\right)^{-1}$ \\
\hline $\mathrm{R}^{\mathrm{B}}$ & Biomass-specific respiration rate & $\mathrm{mg} C(\mathrm{mg} \mathrm{chl} a \mathrm{~d})^{-1}$ \\
\hline $\mathrm{PG}_{y}$ & Annual gross productivity & $g C\left(m^{2} y r\right)^{-1}$ \\
\hline$\overline{\mathrm{Z}}_{\mathrm{p}}$ & Annual mean photic depth & $\mathrm{m}$ \\
\hline $\mathrm{H}$ & Water-column depth & $\mathrm{m}$ \\
\hline $\mathrm{PN}_{\mathrm{wy}}$ & Annual water column net productivity & $g C\left(m^{2} y r\right)^{-1}$ \\
\hline $\mathrm{R}_{\text {wy }}$ & Annual water-column respiration & $\mathrm{gC}\left(\mathrm{m}^{2} \mathrm{yr}\right)^{-1}$ \\
\hline $\mathrm{R}_{\mathrm{py}}$ & Annual photic-zone respiration & $g C\left(m^{2} y r\right)^{-1}$ \\
\hline
\end{tabular}

lated in situ incubations were done in a deck incubator. Samples were exposed to natural sunlight of 8 intensities: $100,55,30,15,8,3,1$, and $0 \%$ of ambient irradiance. On clear days, light entering the deck incubator was attenuated by an additional 25 to $40 \%$ with a neutral density Plexiglas filter positioned over the samples. Hence, photoinhibition, which is unlikely to occur in turbid well-mixed environments (Marra, 1978; Joint and Pomroy, 1981), was never observed. Irradiance within the incubator was continuously recorded with a submersible quantum sensor.

Following incubation, subsamples from each bottle were filtered by gravity or low pressure $(<110 \mathrm{~mm} \mathrm{Hg})$ through Gelman type A/E glass-fiber filters. A $3 \mathrm{ml}$ aliquot of each filtrate and duplicate unfiltered $3 \mathrm{ml}$ aliquots from each bottle were placed in scintillation vials. After adding $0.1 \mathrm{ml}$ of $0.2 \mathrm{~N} \mathrm{HCl}$, each aliquot was bubbled under vacuum for $15 \mathrm{~min}$ while ${ }^{14} \mathrm{CO}_{2}$ was stripped from the sample (Schindler et al., 1972). The residual activity of the sample was measured using a liquid scintillation spectrometer. All carbon uptake rates were corrected for activity of the filtrate (excretion) and dark-bottle uptake.

Maximum daily carbon assimilation rates $\mathrm{P}_{\mathrm{m}}^{\mathrm{B}}$ were derived from chlorophyll a normalized photosynthesisirradiance (P-I) curves. The Gauss-Newton nonlinear least squares technique was used to obtain the best fit of the data to the hyperbolic tangent function (Platt and Jassby, 1976):

$$
\mathrm{P}^{\mathrm{B}}=\mathrm{P}_{\mathrm{m}}^{\mathrm{B}} \tanh \left(\alpha \mathrm{I} / \mathrm{P}_{\mathrm{m}}^{\mathrm{B}}\right)-\mathrm{R}^{\mathrm{B}}
$$

Simulated incubation depths were calculated as $-\ln \left(I_{i} / I_{o}\right) / \varepsilon$, where $I_{1} / I_{o}$ is the fraction of daily surface insolation received by bottle i. Daily photic zone net productivity $\mathrm{PN}_{p d}$ was calculated by integrating (trapezoidal quadrature) measured rates of carbon uptake [mg $\mathrm{C}\left(\mathrm{m}^{3} \mathrm{~d}\right)^{-1}$ ] over the photic depth. Annual photic zone net productivity $\mathrm{PN}_{\mathrm{py}}$ was estimated for each site by integrating $P N_{p d}$ over the year. Baywide the specific respiration rate $R^{B}$, as the intercept of the P-I curves (Steemann Nielsen and Hansen, 1959), averaged $4.5 \%$ of $\mathrm{P}_{\mathrm{m}}^{\mathrm{B}}$ over the year. Since even after a $24 \mathrm{~h}$ incubation it is unlikely that samples held at low-light had reached a net productivity rate (Hobson et al., 1976), the intercepts were probably underestimates of the true specific respiration rate (Peterson, 1980). In previous studies in San Francisco Bay (Peterson et al., in press) a typical respiration rate was found to be about $10 \%$ of $\mathrm{P}_{\mathrm{m}}^{\mathrm{B}}$ using oxygen light-dark bottle techniques in $24 \mathrm{~h}$ incubations. In the analysis presented below, we assumed that $\mathrm{R}^{B}$ was constant and equal to $0.1 \mathrm{P}_{\mathrm{m}}^{\mathrm{B}}$, and calculated annual gross productivity $P_{G_{y}}$ as the sum of annual net productivity and integral respiration over the photic zone.

\section{RESULTS}

Ambient insolation during the course of the experiments (Fig. 2a, 3a, 4a) was similar for all sites and ranged from 8 to 55 Einsteins $\left(m^{2} \mathrm{~d}\right)^{-1}$. Attenuation coefficients varied substantially between embayments and at times between channel and shoal sites within embayments (Fig. 2b, 3b, 4b). Photic depths in South Bay were fairly constant throughout the year and averaged about $3.2 \mathrm{~m}$. In San Pablo Bay large variations in attenuation coefficient resulted in fluctuations of photic depth that ranged from about 0.3 to $6.6 \mathrm{~m}$. Photic depths at both sites in Suisun Bay remained $<1 \mathrm{~m}$ throughout most of the year. The annual range of attenuation coefficients was large at most sites, but based on annual mean attenuation coefficients (Table 2) turbidity in South Bay was less than in San Pablo Bay which was less than in Suisun Bay. In 


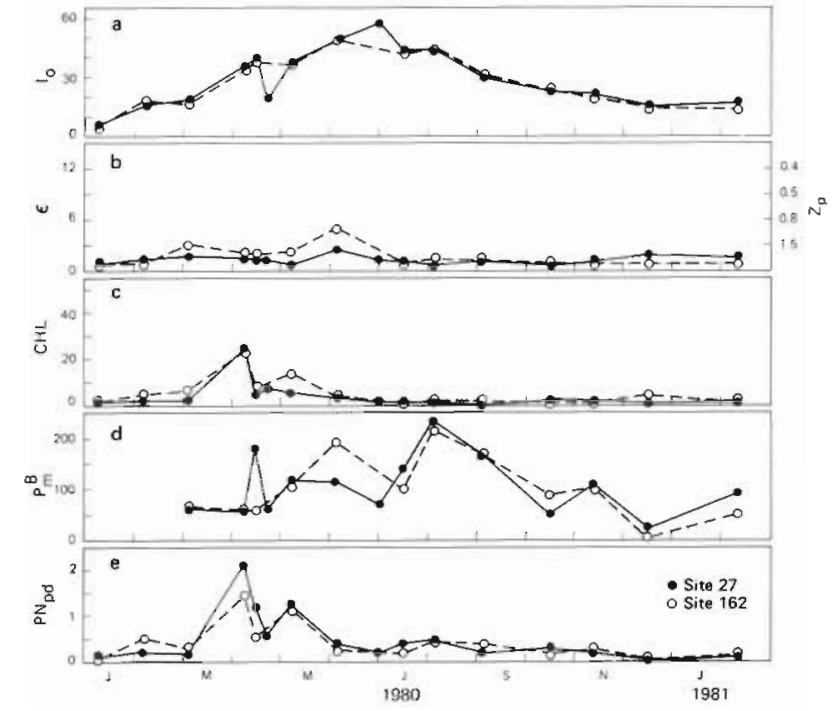

Fig. 2. South Bay. Seasonal variation of (a) ambient irradiance $I_{0}\left(E m^{-2} d^{-1}\right)_{i}$ (b) attenuation coefficient $\varepsilon\left(\mathrm{m}^{-1}\right)$ and photic depth $Z_{\mathrm{p}}(\mathrm{m})$; (c) chlorophyll a CHL $\left(\mathrm{mg} \mathrm{m}^{-3}\right)$; (d) maximum carbon assimilation rate $\mathrm{P}_{\mathrm{m}}^{\mathrm{B}}\left[\mathrm{mg} \mathrm{C}(\mathrm{mg} \mathrm{chl} \mathrm{a} \mathrm{d})^{-1}\right.$; (e) daily net productivity $\mathrm{PN}_{\mathrm{pd}}\left[\mathrm{mg} \mathrm{C}\left(\mathrm{m}^{2} \mathrm{~d}\right)^{-1}\right.$ ] for Incubation Sites 27 (•) and $162(0)$

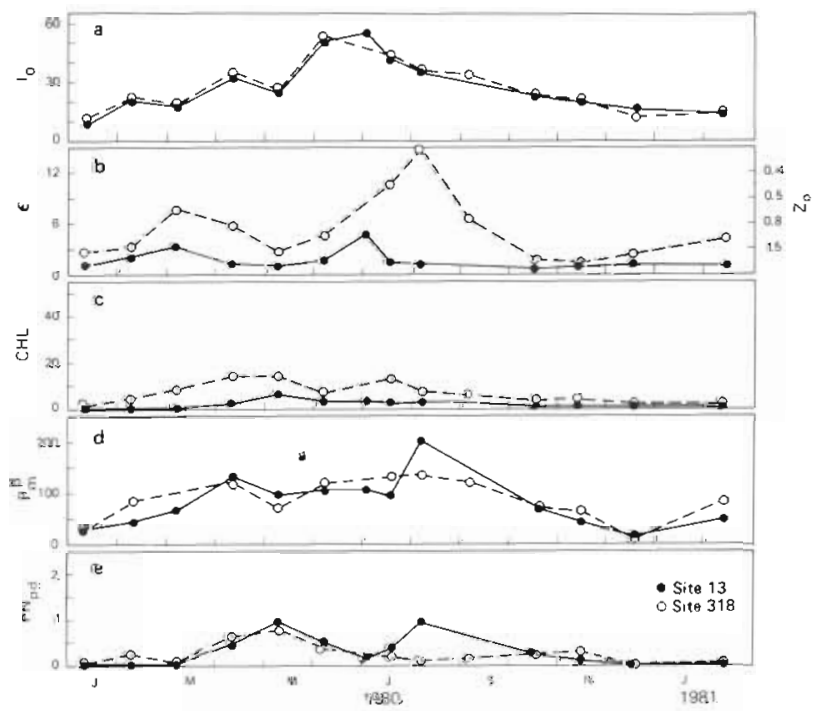

Fig. 3. San Pablo Bay. Seasonal variation of (a) ambient irradiance $\mathrm{I}_{\mathrm{o}}\left(\mathrm{E} \mathrm{m}^{-2} \mathrm{~d}^{-1}\right)$; (b) attenuation coefficient $\mathrm{E}\left(\mathrm{m}^{-1}\right)$ and photic depth $\mathrm{Z}_{\mathrm{p}}(\mathrm{m})$; (c) chlorophyll a $\mathrm{CHL}\left(\mathrm{mg} \mathrm{m}^{-3}\right.$ ); (d) maximum carbon assimilation rate $P_{\mathrm{m}}^{\mathrm{B}}\left[\mathrm{mg} \mathrm{C}(\mathrm{mg} \mathrm{chl} \mathrm{a} \mathrm{d})^{-1}\right.$ ]; (e) daily net productivity $\mathrm{PN}_{\mathrm{pd}}\left[\mathrm{mg} \mathrm{C}\left(\mathrm{m}^{2} \mathrm{~d}\right)^{-1}\right]$ for Incubation Sites $13(\bullet)$ and $318(0)$

addition, attenuation coefficients were consistently greater in the shoals than the channel of San Pablo Bay and Suisun Bay

Although the absolute chlorophyll a level for a given date was typically higher at the shallow water incubation site than at the adjacent channel site, the seasonality of chlorophyll $a$ was similar for the 2 incubation

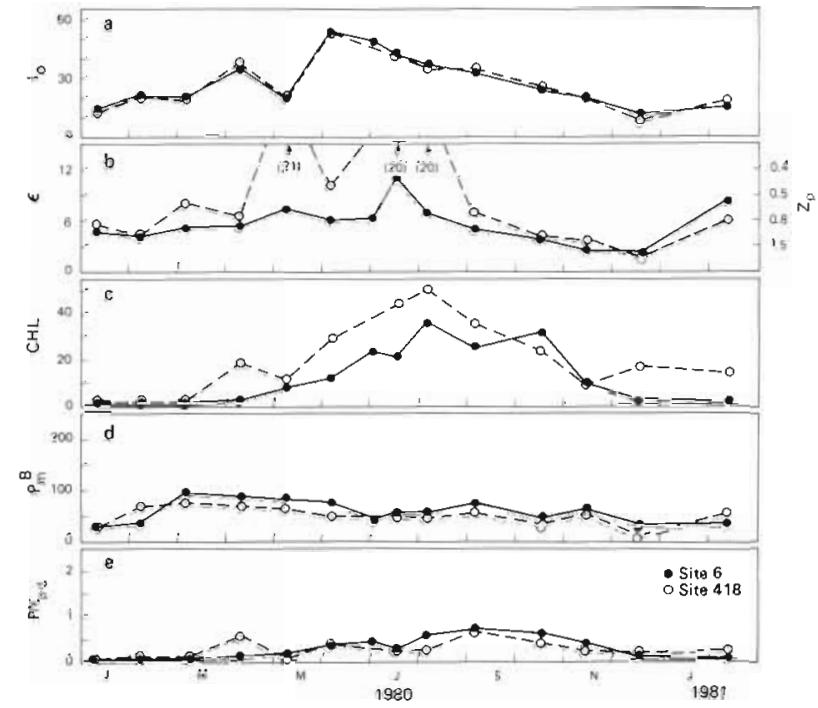

Fig. 4. Suisun Bay. Seasonal variation of (a) ambient irradiance $I_{o}\left(E m^{-2} d^{-1}\right)$; (b) attenuation coefficient $\varepsilon\left(\mathrm{m}^{-1}\right)$ and photic depth $Z_{\mathrm{p}}(\mathrm{m})$; (c) chlorophyll a CHL $\left(\mathrm{mg} \mathrm{m}^{-3}\right)$; (d) maximum carbon assimilation rate $\mathrm{P}_{\mathrm{m}}^{\mathrm{B}}\left[\mathrm{mg} \mathrm{C}(\mathrm{mg} \mathrm{chl} \text { a d })^{-1}\right]$; (e) daily net productivity $\mathrm{PN}_{\mathrm{pd}}\left[\mathrm{mg} \mathrm{C}\left(\mathrm{m}^{2} \mathrm{~d}\right)^{-1}\right]$ for Incubation Sites $6(\bullet)$ and $418(O)$

sites within each embayment and distinct from the seasonality in the other two embayments (Fig. 2c, 3c, 4c). In South Bay (Fig. 2c) there was a late winter-early spring chlorophyll a maximum of approximately $24 \mathrm{mg} \mathrm{m}^{-3}$ after which chlorophyll a levels remained less than about $2 \mathrm{mg} \mathrm{m}^{-3}$. Maximum chlorophyll a levels in San Pablo Bay (Fig. 3c) were observed in spring. The increase and decline in biomass occurred over a longer period at the shoal site than at the deepwater location. Chlorophyll a concentrations at San Pablo Bay sites ranged from 0.7 to $6.4 \mathrm{mg} \mathrm{m}^{-3}$ at Station 13 and from 1.5 to $14.4 \mathrm{mg} \mathrm{m}^{-3}$ at Station 318 . Maximum concentrations of chlorophyll $a$ at the Suisun Bay incubation sites (Fig. 4c) exceeded those from the other 2 embayments. Winter lows of $<1 \mathrm{mg}$ chl a $\mathrm{m}^{-3}$ were followed by a gradual increase to summer maxima of 35 and $50 \mathrm{mg} \mathrm{chl} \mathrm{a} \mathrm{m}^{-3}$ at the deepwater and shallow-water sites respectively.

Daily carbon assimilation rates were usually similar at both incubation sites within each embayment (Fig. $2 \mathrm{~d}, 3 \mathrm{~d}, 4 \mathrm{~d}$ ). Although seasonality in $\mathrm{P}_{\mathrm{m}}^{\mathrm{B}}$ was similar at Sites 27, 162, and 13, it differed among the other sampling sites. In South Bay and San Pablo Bay, $\mathrm{P}_{\mathrm{m}}^{\mathrm{B}}$ generally increased from winter lows $\left(\mathrm{P}_{\mathrm{m}}^{\mathrm{B}}\right.$ rates in South Bay were not attained in January or February) to maximum rates in midsummer. Low winter $\mathrm{P}_{\mathrm{m}}^{\mathrm{B}}$ rates in Suisun Bay were followed by annual maximum values in March after which there was a gradual decline in $\mathrm{P}_{\mathrm{m}}^{\mathrm{B}}$ over the year. Baywide, winter minimum $\mathrm{P}_{\mathrm{m}}^{\mathrm{B}}$ rates were 25 to $30 \mathrm{mg} \mathrm{C}(\mathrm{mg} \mathrm{chl} \mathrm{a} \mathrm{d})^{-1}$, whereas maximum rates ranged from $230 \mathrm{mg} \mathrm{C}(\mathrm{mg} \mathrm{chl} \mathrm{a} \mathrm{d})^{-1}$ in South Bay to 
Table 2. Annual mean and range of attenuation coefficient $(\varepsilon)$, photic depth $\left(\bar{Z}_{\mathrm{p}}\right)$, water depth $(\mathrm{H})[\mathrm{MLLW}$ water depth $+1 \mathrm{~m}]$, and $\mathrm{H} / \bar{Z}_{\mathrm{p}}$ ratio for the 6 incubation sites

\begin{tabular}{|c|c|c|c|c|c|c|}
\hline Station & & $\varepsilon\left(\mathrm{m}^{-1}\right)$ & Range & $\bar{z}_{p}(m)$ & $\mathrm{H}(\mathrm{m})$ & $\mathrm{H} / \overline{\mathrm{Z}}_{\mathrm{p}}$ \\
\hline South Bay & $\begin{array}{r}27 \\
162\end{array}$ & $\begin{array}{l}1.3 \\
1.7\end{array}$ & $\begin{array}{l}0.7-2.5 \\
0.8-5.1\end{array}$ & $\begin{array}{l}3.5 \\
2.7\end{array}$ & $\begin{array}{l}12 \\
3.0\end{array}$ & $\begin{array}{l}3.4 \\
1.1\end{array}$ \\
\hline San Pablo Bay & $\begin{array}{r}13 \\
318\end{array}$ & $\begin{array}{l}1.8 \\
5.6\end{array}$ & $\begin{array}{l}0.7-4.7 \\
1.4-15\end{array}$ & $\begin{array}{l}2.6 \\
0.8\end{array}$ & $\begin{array}{l}11 \\
2.2\end{array}$ & $\begin{array}{l}4.2 \\
2.8\end{array}$ \\
\hline Suisun Bay & $\begin{array}{r}6 \\
418\end{array}$ & $\begin{array}{l}5.7 \\
9.6\end{array}$ & $\begin{array}{l}2.4-11 \\
3.6-21\end{array}$ & $\begin{array}{l}0.8 \\
0.5\end{array}$ & $\begin{array}{l}10 \\
1.6\end{array}$ & $\begin{array}{r}12.5 \\
3.2\end{array}$ \\
\hline
\end{tabular}

approximately 170 in San Pablo Bay and $83 \mathrm{mg} \mathrm{C}$ (mg chl $a \mathrm{~d})^{-1}$ in Suisun Bay.

Although seasonality in daily net productivity (Fig. $2 e, 3 e, 4 e)$ was generally similar to the pattern observed for chlorophyll $a$ at each of the 6 incubation sites, baywide the levels of productivity had little relation to chlorophyll a concentration. At both sites in South Bay (Fig. 2e) the annual pattern in $\mathrm{PN}_{\mathrm{pd}}$ was dominated by 2 peaks in early spring of 1.2 to $2.2 \mathrm{~g}$ $\mathrm{C}\left(\mathrm{m}^{2} \mathrm{~d}\right)^{-1}$. At all other times during the year produc-

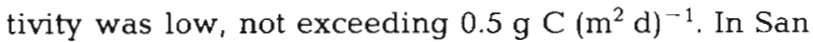
Pablo Bay low $\left[<0.05 \mathrm{~g} \mathrm{C}\left(\mathrm{m}^{2} \mathrm{~d}\right)^{-1}\right.$ ] levels of productivity in winter (Fig. 3e) were followed by a peak in spring at both the channel and shoal sites coincident with peaks in chlorophyll a. At the channel site a second peak in productivity, of similar magnitude to the spring peak, occurred simultaneously with a marked increase in $\mathrm{P}_{\mathrm{m}}^{\mathrm{B}}$ (Fig. 3d) and decreased turbidity (Fig. 3b). In Suisun Bay extremely low productivity during winter (Fig. 4e) preceded increased $P N_{p d}$ that was coincident with the summer increase of chlorophyll a. Even though biomass in Suisun Bay was the highest observed throughout the San Francisco Bay system, maximum levels of phytoplankton productivity

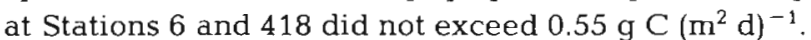
Annual net productivity $\mathrm{PN}_{\mathrm{py}}$ over the photic zone was 150,110 to 130 , and $95 \mathrm{~g} \mathrm{C} \mathrm{m}^{-2}$ for the South Bay, San Pablo Bay, and Suisun Bay sites respectively.

\section{DISCUSSION}

\section{Predicting daily productivity}

Although the seasonality of parameters that potentially control phytoplankton productivity in San Francisco Bay was diverse, $\mathrm{PN}_{\mathrm{pd}}$ was primarily a function of phytoplankton biomass and light availability. Falkowski (1981) has also derived an empirical function that relates integral productivity to $B$ and $I_{o}$ in the New York Bight. Gieskes and Kraay (1977) similarly conclude that the productivity of surface-water samples in the Southern North Sea can be estimated well from chlorophyll a concentration and incident light. When all measured values of $\mathrm{PN}_{\mathrm{pd}}$ were regressed against the simple composite parameter B $\mathrm{I}_{\mathrm{o}} / \varepsilon$ (Table 3; Fig. 5), we found that, both within individual embayments and baywide, about $80 \%$ of the seasonal variability in $\mathrm{PN}_{\mathrm{pd}}$ was correlated with this simple parameter. Therefore, nutrient availability, temperature, and physiological state of the phytoplankton play only minor roles in regulating productivity. All linear regressions were highly significant $(\mathrm{I}=0.88$ to $0.97, \mathrm{P}<0.001$ ) and indicated that this relation held over a wide range of $\mathrm{I}_{a} \varepsilon, \mathrm{B}, \mathrm{P}_{\mathrm{m}}^{\mathrm{B}}$ and phytoplankton communities.

$\mathrm{PN}_{\mathrm{pd}}$ was consistently predicted well using this composite parameter, whereas correlations between $\mathrm{PN}_{\mathrm{pd}}$ and either $\mathrm{I}_{o} / \varepsilon, \mathrm{I}_{0}, \varepsilon$, or $\mathrm{P}_{\mathrm{m}}^{\mathrm{B}}$ were weak (Table 3 ). Because carbon uptake is dependent on phytoplankton biomass, it is common practice to normalize productivity by the chlorophyll a content of the sample. Within a localized area, even normalizing integral productivity to photic zone chlorophyll a at times during the year (Malone, 1977; Bruno et al., 1983) aids in determining the factors regulating phytoplankton production. In San Francisco Bay there was a significant correlation $(\mathrm{P}<0.05)$ between $\mathrm{PN}_{\mathrm{pd}}$ and phytoplankton biomass (B) at 5 of the 6 incubation sites (Table 3). In each embayment the seasonal pattern in productivity was generally reflective of the seasonality in biomass (Fig. 2c, e; 3c, e; 4c, e). Except at Site 418, variations solely in chlorophyll a accounted for more than $50 \%$ of the variation in observed $\mathrm{PN}_{\mathrm{pd}}$ (Table 3). Within a restricted environmental setting (i.e. separate embayments), changes in chlorophyll a concentration accounted for most of the variation in productivity. However, only $12 \%$ of the baywide annual variation in productivity was correlated with changes in biomass. Because there was a wide range in slopes (6.5 to 156 ; data not shown) for regressions between productivity and chlorophyll $a$ at the 6 sites, the single regression of $\mathrm{PN}_{\mathrm{pd}}$ and $\mathrm{B}$ data from all sites accounted for only a small fraction (12\%) of the variation in $\mathrm{PN}_{\mathrm{pd}}$ baywide (Table 3 ). Thus, although at a given location phyto- 
plankton biomass was indicative of photic-zone productivity, our results suggest that the use of chlorophyll a alone is of little value in predicting $\mathrm{PN}_{\mathrm{pd}}$ among diverse areas. This is consistent with the conclusions of Cadée and Hegeman (1974) and Boynton et al. (1982) that over a wide range of environmental conditions or aquatic environments productivity cannot be estimated from measures of chlorophyll a alone.
Iate well with changes in $\mathrm{P}_{\mathrm{m}}^{\mathrm{B}}$ (Table 3). The poor correlation between primary productivity and $\mathrm{P}_{\mathrm{m}}^{\mathrm{B}}$ probably results from the fact that productivity is largely determined by biomass, and that spatio-temporal variations in biomass within San Francisco Bay are not controlled by the same processes that regulate growth rate (i.e. $\mathrm{P}_{\mathrm{m}}^{\mathrm{B}}$ ). For example, the summer biomass maximum in Suisun Bay results from the physical accumulation of

Table 3. Coefficients of determination $\left(\mathrm{r}^{2}\right)$ from linear regressions of photic zone productivity ( $\left.\mathrm{PN}_{\mathrm{pd}}\right)$ against $\mathrm{B} \mathrm{I}_{\mathrm{o}} / \varepsilon_{\mathrm{r}}$ chlorophyll a (B), $\mathrm{I}_{\mathrm{o}} / \varepsilon_{\mathrm{r}}$ ambient irradiance $\left(\mathrm{I}_{o}\right)$, attenuation coefficient $(\varepsilon)$, and carbon assimilation rate $\left(\mathrm{P}_{\mathrm{m}}^{\mathrm{B}}\right)$

\begin{tabular}{|c|c|c|c|c|c|c|c|c|}
\hline Station & & $\mathrm{n}$ & $\mathrm{B} \mathrm{I} / \varepsilon$ & B & $\mathrm{I}_{\mathrm{o}} / \varepsilon$ & $\mathrm{I}_{\mathrm{o}}$ & $\varepsilon$ & $\mathrm{P}_{\mathrm{m}}^{\mathrm{B}}$ \\
\hline Baywide & & 77 & $0.82^{\cdots}$ & $0.12^{\circ}$ & $0.14^{\circ}$ & $0.15^{\circ}$ & 0.03 & $0.08^{\circ}$ \\
\hline South Bay & $\begin{array}{r}27 \\
162\end{array}$ & $\begin{array}{l}15 \\
13\end{array}$ & $\begin{array}{l}0.90^{\circ} \\
0.89^{\circ}\end{array}$ & $\begin{array}{l}0.77^{\circ} \\
0.84^{\circ}\end{array}$ & $\begin{array}{l}0.08 \\
0.00\end{array}$ & $\begin{array}{l}0.10 \\
0.15\end{array}$ & $\begin{array}{l}0.00 \\
0.06\end{array}$ & $\begin{array}{l}0.01 \\
0.00\end{array}$ \\
\hline San Pablo & $\begin{array}{r}13 \\
318\end{array}$ & $\begin{array}{l}12 \\
12\end{array}$ & $\begin{array}{l}0.78^{\cdots} \\
0.94^{\cdots}\end{array}$ & $\begin{array}{l}0.66^{\circ} \\
0.51^{\circ}\end{array}$ & $\begin{array}{l}0.43^{\circ} \\
0.19\end{array}$ & $\begin{array}{l}0.17 \\
0.16\end{array}$ & $\begin{array}{l}0.07 \\
0.03\end{array}$ & $\begin{array}{l}0.66^{\circ} \\
0.08\end{array}$ \\
\hline Suisun Bay & $\begin{array}{r}6 \\
418\end{array}$ & $\begin{array}{l}13 \\
12\end{array}$ & $\begin{array}{l}0.89 \cdots \\
0.82 \%\end{array}$ & $\begin{array}{l}0.82 \cdots \\
0.29\end{array}$ & $\begin{array}{l}0.36^{\circ} \\
0.39^{\circ}\end{array}$ & $\begin{array}{l}0.26 \\
0.37^{\circ}\end{array}$ & $\begin{array}{l}0.00 \\
0.01\end{array}$ & $\begin{array}{l}0.01 \\
0.01\end{array}$ \\
\hline
\end{tabular}

In addition to phytoplankton biomass, productivity in estuaries is commonly believed to be a function of photic-zone irradiance because there is decreased productivity in turbid regions relative to clearer waters (Flemer, 1970; Cadée and Hegeman, 1974; Malone, 1977; Cadée, 1978; Colijn, 1978; Stockner et al., 1979; Joint and Pomroy, 1981). However, the most appropriate means of quantifying the light available to phytoplankton in a photic zone is not obvious. Photosynthetically available light must be related to both ambient light $\left(I_{0}\right)$ and the depth of the photic zone, a measure derived from the attenuation coefficient $(\varepsilon)$. We assumed that $\varepsilon, \mathrm{I}_{o}$, and $\mathrm{I}_{\mathrm{o}} / \varepsilon$, as indices of light availability, might be useful predictors of daily productivity. At some sites the use of $\mathrm{I}_{o}$ and $\mathrm{I}_{o} / \varepsilon$ increased the predictability of $\mathrm{PN}_{p d}$ (Table 3 ). But neither $\varepsilon, \mathrm{I}_{o}$ or $\mathrm{I}_{o} / \varepsilon$ individually accounted for more than $43 \%$ of the variation in daily productivity. The poor relationship between $\mathrm{PN}_{\mathrm{pd}}$ and $\varepsilon$ was surprising because there was a significant relationship between $\mathrm{PN}_{\mathrm{py}}$ and annual mean photic depth $\bar{Z}_{p}$, which was calculated from $\varepsilon$ (Fig. 6).

Positive correlations are reported between photic zone productivity and $\mathrm{P}_{\mathrm{m}}^{\mathrm{B}}$ in some estuaries (Williams and Murdoch, 1966; Malone, 1977), but in San Francisco Bay changes in $\mathrm{PN}_{\mathrm{pd}}$ were poorly correlated with $\mathrm{P}_{\mathrm{m}}^{\mathrm{B}}$ (Table 3). In South Bay and San Pablo Bay, $\mathrm{P}_{\mathrm{m}}^{\mathrm{B}}$ generally increased until midsummer, whereas $\mathrm{PN}_{\mathrm{pd}}$ was maximum in spring. In contrast, maximum $P N_{p d}$ in Suisun Bay was observed in summer, whereas maximum $\mathrm{P}_{m}^{\mathrm{B}}$ was seen in late winter. Over the year-long study, only at Station 13 did variations in $\mathrm{PN}_{\mathrm{pd}}$ corre-

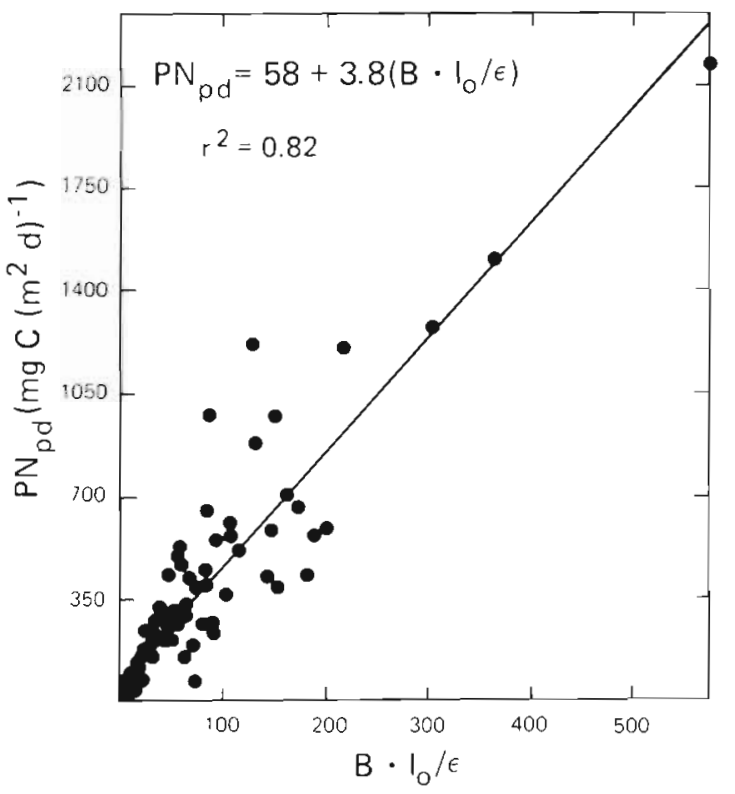

Fig. 5. Regression of daily net productivity $\mathrm{PN}_{\mathrm{pd}}$ against composite parameter $\mathrm{B} \mathrm{I}_{\mathrm{o}} / \varepsilon$

phytoplankton by estuarine circulation, rather than from rapid growth rates (Cloern et al., 1983), and the spring bloom in South Bay results partly from decreased benthic grazing pressure when the water column is stratified (Cloern, 1982). Only in estuaries where biomass and carbon assimilation rates are controlled by the same processes (e.g. specific growth rate) 


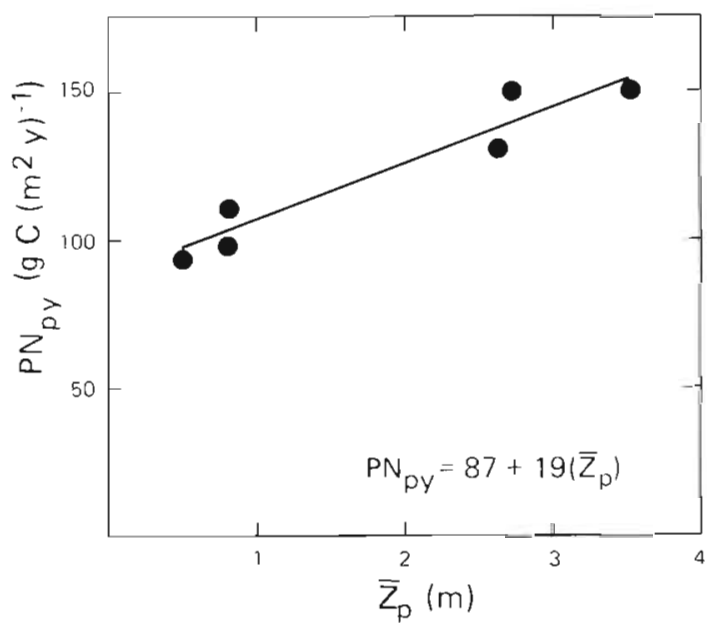

Fig. 6. Annual net productivity $\mathrm{PN}_{\mathrm{py}}$ as a function of annual mean photic depth $\bar{Z}_{p}$ at the 6 incubation sites

would a strong correlation between productivity and $\mathrm{P}_{\mathrm{m}}^{\mathrm{B}}$ be expected.

\section{Predicting net water-column productivity}

The high turbidity of estuaries has a profound impact not only on gross production but also upon the fraction of gross production available to higher trophic levels. Estuaries are generally shallow, but a large portion of the water column is aphotic or exposed to low irradiance. Because photosynthesis is restricted to the photic zone $\left(Z_{p}\right)$, respiratory losses, which occur over the entire water-column depth $(\mathrm{H})$, can greatly reduce net productivity when the ratio $\mathrm{H} / \mathrm{Z}_{\mathrm{p}}$ becomes large. The importance of the interaction between surface irradiance, mixed depth, photic depth, and production : respiration ratios in regulating productivity was first noted by Gran and Braarud (1935). Their concepts were developed into mathematical models (Sverdrup, 1953; Patten, 1968) to define the 'critical depth' for integral production (i.e. the depth at which respiration in the water column equals carbon production in the photic zone). By examining the mixed depth : photic depth ratio and making assumptions regarding the constancy of the production : respiration ratio (Harris, 1978), one can define conditions which control the seasonality of phytoplankton blooms in marine and freshwater environments (Parsons and Takahashi, 1973; Harris, 1978). Although $H / Z_{p}$ ratios vary widely in estuaries, the concept of critical depth has not been proposed as an explanation for the differences in productivity observed in different estuaries or the temporal changes in productivity or biomass within an estuarine system. Our data suggest that the concept of critical depth is applicable to estuarine systems and that the fraction of gross primary production which is potentially available for higher trophic levels can be estimated from the ratio $\mathrm{H} / \mathrm{Z}_{\mathrm{p}}$. In these calculations we assume that mixed depth is equal to water depth, a condition which is typical in San Francisco Bay.

Assuming vertical homogeneity and that respiration rate equals $0.1 \mathrm{P}_{\mathrm{m}}^{\mathrm{B}}$, annual water column respiration $\mathrm{R}_{\text {wy }}$ can be calculated as:

$$
\mathrm{R}_{w y}=\int_{1}^{365}\left(0.1 \mathrm{P}_{\mathrm{m}}^{\mathrm{B}} \mathrm{B} \mathrm{H}\right) \mathrm{dt}
$$

Similarly, annual respiratory losses in the photic zone $R_{p y}$ can be estimated by substituting $\bar{Z}_{p}$ for $H$ in equation 2 . We estimate that annual gross phytoplankton productivity $\left(\mathrm{PG}_{\mathrm{y}}=\mathrm{PN}_{\mathrm{py}}+\mathrm{R}_{\mathrm{py}}\right.$ ) at the 6 sites ranged from 110 to $190 \mathrm{~g} \mathrm{C} \mathrm{m}^{-2}$ and over the year respiration throughout the water column ranged from 49 to $250 \mathrm{~g} \mathrm{C} \mathrm{m}^{-2}$ (Table 4).

Because $\bar{Z}_{p}$ may be small relative to $H$, respiratory loss can cause some locations to be a net sink rather than a source of phytoplankton carbon (compare $\mathrm{PG}_{\mathrm{y}}$ and $R_{w y}$ for Site 6 in Table 4). The fraction of $P_{y}$ remaining after $R_{w y}$ is accounted for is:

$$
\mathrm{PN}_{w y} / \mathrm{PG}_{y}=\left(\mathrm{PG}_{y}-\mathrm{R}_{w y}\right) / \mathrm{PG}_{y}
$$

The ratio $\mathrm{PN}_{w y} / \mathrm{PG}_{\mathrm{y}}$ (net productivity : gross productivity) was small or negative at deep (large $H$ ) and turbid (small $\bar{Z}_{p}$ ) sites (Table 4 ), which suggests that $\mathrm{PN}_{w y} / \mathrm{PG}_{y}$ may be a simple function of the ratio $\mathrm{H} / \overline{\mathrm{Z}}_{\mathrm{p}}$. Given the constraint that the limit of $\mathrm{PN}_{w y} / \mathrm{PG}_{Y}=1$ as $R_{w y}$ (i.e. $H$ ) approaches zero (Eq. 3), values of $P N_{w y} / P_{G_{y}}$ for the 6 sites were, in fact, linearly related to $H / \bar{Z}_{p}$ (Fig. 7):

$$
\mathrm{PN}_{w y} / \mathrm{PG}_{\mathrm{y}}=1-0.166\left(\mathrm{H} / \overline{\mathrm{Z}}_{\mathrm{p}}\right)
$$

The intercept of this function defines that critical ratio $\mathrm{H} / \overline{\mathrm{Z}}_{\mathrm{p}}$ above which net production becomes negative. On an annual basis for San Francisco Bay, this critical value was $H / \bar{Z}_{p}=6$ (Fig. 7). Sverdrup (1953), in describing the conditions necessary for the onset of a spring bloom in the Norwegian Sea, concludes that when the mixed depth exceeds the production zone depth by 5 times the population decreases. In Lake Windermere values of mixed depth: photic depth between 3 and 4 are typical during low chlorophyll a periods, and chlorophyll a levels rise when the ratio decreases (Talling, 1971).

The need for reliable estimates of specific respiration rate has been noted by numerous researchers. Estimates of respiration in the literature range from $4 \%$ (Platt and Jassby, 1976) to 50\% (Eppley and Sharp, 1975) of maximum assimilation rate. In San Francisco Bay $R^{B}$ is generally 8 to $30 \%$ of $\mathrm{P}_{\mathrm{m}}^{\mathrm{B}}$ (Peterson et al., in press). The $10 \%$ respiration value used in these calcu- 
Table 4. Annual gross productivity in the photic zone $\left(\mathrm{PG}_{\mathrm{y}}\right)$, net productivity in the photic zone (PN $\left.\mathrm{Py}_{\mathrm{p}}\right)$, water column respiration $\left(\mathrm{R}_{\mathrm{wy}}\right)$, and ratio of water column net productivity to gross productivity $\left(\mathrm{PN}_{\mathrm{wy}} / \mathrm{PG}_{\mathrm{y}}\right)$

\begin{tabular}{|crccrr|}
\hline Station & & $\mathrm{PG}_{y}\left(\mathrm{~g} \mathrm{C} \mathrm{m}^{-2}\right)$ & $\mathrm{PN}_{p y}\left(\mathrm{~g} \mathrm{C} \mathrm{m}^{-2}\right)$ & $\mathrm{R}_{\mathrm{wy}}\left(\mathrm{g} \mathrm{C} \mathrm{m}^{-2}\right)$ & $\mathrm{PN}_{\mathrm{wy}} / \mathrm{PG}_{\mathrm{y}}$ \\
\hline South Bay & 27 & 190 & 150 & 120 & .34 \\
San Pablo & 162 & 180 & 150 & 49 & .72 \\
Suisun Bay & 13 & 160 & 130 & 98 & .39 \\
& 318 & 140 & 98 & 250 & .56 \\
\end{tabular}

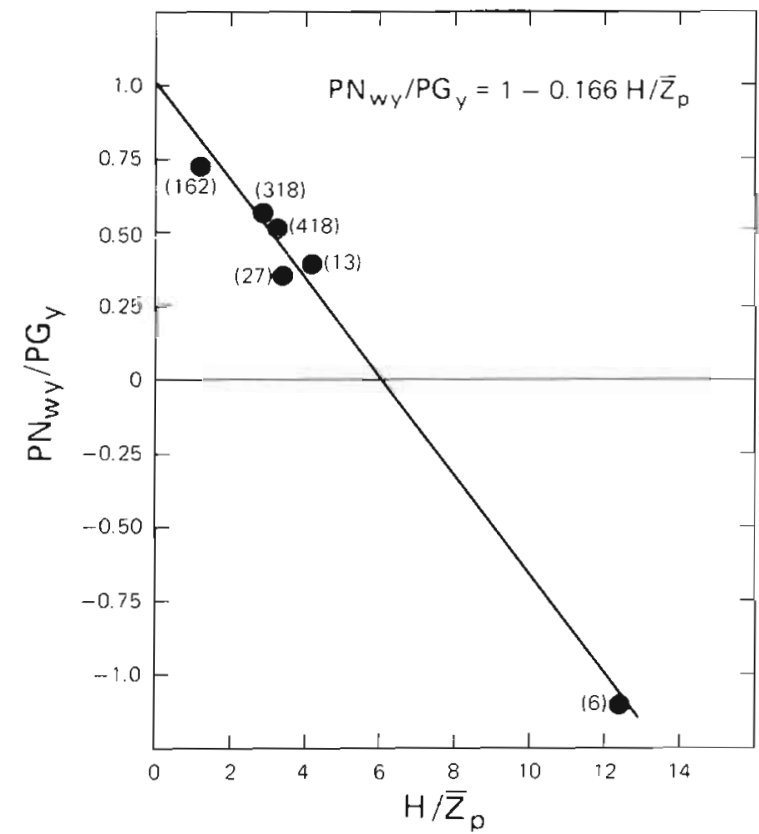

Fig. 7. Ratio of water-column net productivity to gross productivity $\mathrm{PN}_{\mathrm{wy}} / \mathrm{PG}_{\mathrm{y}}$ as a function of $\mathrm{H} / \mathrm{Z}_{\mathrm{p}}$

lations is probably reasonable or conservative. If respiration rates are actually higher, say $25 \%$ of $\mathrm{P}_{\mathrm{m}}^{\mathrm{B}}$ (Falkowski and Owens, 1978), then water column respiration would be 2.5 times greater and an even smaller fraction of phytoplankton production would be available to grazers (see below).

\section{Carbon available to higher trophic levels}

Implications of the critical depth concept also lead to the conclusion that not only do variations in $\mathrm{H} / \mathrm{Z}_{\mathrm{p}}$ ratios have profound consequences for phytoplankton population dynamics, but also that the availability of phytoplankton carbon to higher trophic levels varies with changes in this ratio. From Equation 4 and as shown in Fig. 7 , the fraction of gross phytoplankton production available to herbivores can be estimated from the ratio $\mathrm{H} / \overline{\mathrm{Z}}_{\mathrm{p}}$. High standing stocks of phytoplankton (chloro- phyll a) are often considered to be indicative of abundant food for higher trophic levels. As shown by our results, such a presumption may be misleading. For example, Site 6 in Suisun Bay had the highest concen-

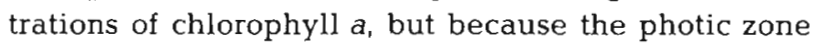
was only a small fraction of the water-column depth (Table 2), respiratory losses exceeded gross primary production (Table 4). Baywide, there was a greater fraction of production available for herbivores at the shallow-water sites $(162,318,418)$, where the ratio $\mathrm{H} / \overline{\mathrm{Z}}_{\mathrm{p}}$ was smaller (Fig. 7), than at the deep-water sites $(27,13,6)$. The extensive shallow areas of San Francisco Bay in general, and Suisun Bay in particular, must be Iargely responsible for maintaining the system's capacity to support herbivore populations. An estuary's capability to support higher trophic levels should thus depend in part on the size and relative proportion of areas with low and high ratios of $H / Z_{p}$ rather than solely depend on phytoplankton biomass.

These findings imply 2 general conclusions. First, in deep turbid channels (e.g. Suisun Bay) the requirements for cell maintenance (respiration) are such that phytoplankton populations cannot be maintained by in situ growth. Rather, as postulated by Cloern and Cheng (1981) and Cloern et al. (1983), the populations found in these areas must be advected in from areas with conditions more favorable for growth (i.e. lower $\mathrm{H} / \mathrm{Z}_{\mathrm{p}}$ ratios). Second, the nutritional mode of herbivores might vary with turbidity. Areal productivity decreases with increasing turbidity (Fig. 6, this paper; Cadée and Hegeman, 1974; Malone, 1977; Cadée, 1978; Colijn, 1978; Joint and Pomroy, 1981), and a large fraction of phytoplankton carbon is lost through respiration in deep, turbid environments. Therefore, either the biomass of herbivores should decline in turbid environments or higher trophic levels in such environments must depend to a large degree on suspended detritus or particulate organic carbon in the sediments. Consumers in a turbid environment may therefore be less dependent upon phytoplankton production as a food source than consumers in clearer waters. Because the nutritional value of detritus is 
lower than that of phytoplankton (Kirby-Smith, 1976; Heinle et al., 1977) and there is a negative relation between the percentage of detritus in the diet and growth of copepods (Heinle et al., 1977; Chervin, 1978; Chervin et al., 1981) and scallops (Kirby-Smith, 1976), one might expect to see lower macrofauna biomass in areas where there is a greater dependence on detrital carbon than phytoplankton carbon for food.

The diet for the individual species has not been studied, but distributions of zooplankton and benthic animals in San Francisco Bay support these hypotheses. In the 3 major embayments, biomass of zooplankton and benthic infauna are greater where turbidity is low, the ratio $H / \bar{Z}_{\mathrm{p}}$ is low, and there is a large proportion of phytoplankton carbon available for consumers. The average fraction of gross phytoplankton production available for consumption by herbivores in South Bay, San Pablo Bay, and Suisun Bay was 53, 48 , and $-29 \%$ respectively (mean $\mathrm{PN}_{w y} / \mathrm{PG}_{y}$ ratio of channel and shoal sites from Table 4). Mean annual zooplankton biomass during 1980 was 21,16 , and $9.9 \mathrm{mg} \mathrm{C} \mathrm{m}{ }^{-3}$ in these same embayments (Hutchinson 1982a, b). Similarly, Thompson and Nichols (1981) report that, based on data collected in 1973, wet weight biomass of benthic macrofauna is greatest in South Bay $\left(4800 \mathrm{~g} \mathrm{~m}^{-2}\right)$ and least in Suisun Bay $\left(100 \mathrm{~g} \mathrm{~m}^{-2}\right)$ with levels in San Pablo Bay $\left(520 \mathrm{~g} \mathrm{~m}^{-2}\right)$ being intermediate between the two.

The results of our study show that daily photic zone net primary productivity in San Francisco Bay can be estimated from a simple function: $\mathrm{PN}_{\mathrm{pd}}=58+3.8$ $\left(B \mathrm{I}_{\mathrm{o}} / \varepsilon\right)$. Moreover, the fraction of phytoplankton carbon production available for higher trophic levels can be estimated from the ratio $\mathrm{H} / \overline{\mathrm{Z}}_{\mathrm{p}}$. Thus, the capability of this complex ecosystem to support secondary production can be predicted from simple, easily measured parameters. However, it should be noted that the accuracy of calculated net water-column productivity is dependent upon accurate measures of phytoplankton respiration, a process which is not easily measured and which may be variable.

Acknowledgements. We thank Andrea Alpine for supplying the chlorophyll a data, assisting in collecting the productivity data, and for many helpful discussions and criticisms during field work and manuscript preparation. We also appreciate the assistance of Anne Hutchinson, Peter Alexander, Sally Wienke, and Suzanne Cartegana in collecting and analyzing the data. Valuable ideas and criticisms were provided by Janet Thompson, Steven Hager, and Frank Triska during analysis of the results and writing of the paper

\section{LITERATURE CITED}

Boynton, W. R., Kemp, W. M., Keefe, C. W. (1982). A comparative analysis of nutrients and other factors influencing estuarine phytoplankton production. In: Kennedy, V. S. (ed.) Estuarine comparisons. Academic Press, New York

Bruno, S. G., Staker, R. D., Sharma, G. M., Turner, J. T. (1983). Primary productivity and phytoplankton size fraction dominance in a temperate North Atlantic estuary. Estuaries 6: 200-211

Cadée, G. C. (1978). Primary production and chlorophyll in the Zaire River, estuary and plume. Neth. J. Sea Res. 12 368-381

Cadée, G. C., Hegeman, J. (1974). Primary production of phytoplankton in the Dutch Wadden Sea. Neth. J. Sea Res. 8: $240-259$

Chervin, M. B. (1978). Assimilation of particulate organic carbon by estuarine and coastal copepods. Mar. Biol. 49: 265-275

Chervin, M. B., Malone, T. C., Neale, P. J. (1981). Interactions between suspended organic matter and copepod grazing in the plume of the Hudson River. Estuar, coast. Shelf Sci 13: $169-183$

Cloern, J. E. (1982). Does the benthos control phytoplankton biomass in South San Francisco Bay? Mar. Ecol. Prog. Ser. 9: $191-202$

Cloern, J. E. (1984). Temporal dynamics and ecological significance of salinity stratification in an estuary (South San Francisco Bay, USA). Oceanol. Acta (in press)

Cloern, J. E., Cheng, R. T. (1981). Simulation model of Skeletonema costatum population dynamics in Northern San Francisco Bay, California. Estuar. coast. Shelf Sci. 12; $83-100$

Cloern, J. E., Alpine, A. E., Cole, B. E., Wong, R. L. J., Arthur, J. F., Ball, M. D. (1983). River discharge controls phytoplankton dynamics in the northern San Francisco Bay estuary. Estuar. coast. Shelf Sci. 16: 415-429

Colijn, F. (1978). Primary production measurements in the Ems-Dollard estuary during 1975 and 1976. Publikates en Verslagen Biologish Onderzoek Eems-Dollard Estuariam 1: $1-14$

Conomos, T. J. (1979). Properties and circulation of San Francisco Bay waters. In: Conomos, T. J. (ed.) San Francisco Bay: the urbanized estuary. Pacific Division, AAAS, San Francisco, p. 47-84

Conomos, T. J., Smith, R. E., Peterson, D. H., Hager, S. W., Schemel, L. E. (1979). Processes affecting seasonal distributions of water properties in the San Francisco Bay estuarine system. In: Conomos, T. J. (ed.) San Francisco Bay: the urbanized estuary, Pacific Division, AAAS, San Francisco, p. 115-142

Eppley, R. W., Sharp, J. (1975). Photosynthetic measurements in the central north Pacific: the dark loss of carbon in $24-\mathrm{h}$ incubations. Limnol. Oceanogr. 20: 981-987

Falkowski, P. G. (1981). Light-shade adaptation and assimilation numbers. J. Plankton Res. 3: 203-216

Falkowski, P. G., Owens, T. G. (1978). Effects of light intensity on photosynthesis and dark respiration in six species of marine phytoplankton. Mar. Biol. 45: 289-295

Flemer, D. (1970). Primary production in Chesapeake Bay. Chesapeake Sci. 11: 117-129

Gieskes, W. W. C., Kraay, G. W. (1977). Primary production and consumption of organic matter in the southern North Sea during the spring bloom of 1975 . Neth. J. Sea Res. 11: 146-167

Gran, H. H., Braarud, $\Upsilon$. (1935). A quantitative study of the phytoplankton in the Bay of Fundy and the Gulf of Maine (including observations of hydrography, chemistry, and turbidity). J. biol. Bd Can. 1: 279-467

Harris, G. P. (1978). Photosynthesis, productivity, and growth: 
the physiological ecology of phytoplankton. Arch. Hydrobiol. 10: 1-171

Heinle, D. R., Harris, R. P., Ustach, J. F., Flemer, D. A. (1977). Detritus as food for estuarine copepods. Mar. Biol. 40: 341-353

Hobson, L. A., Morris, W. J., Pirquet, K. T. (1976). Theoretical and experimental analysis of the ${ }^{14} \mathrm{C}$ technique and its use in studies of primary production. J. Fish. Res. Bd Can. 33: $1715-1721$

Hutchinson, A. (1981). Plankton studies in San Francisco Bay. III. Zooplankton species composition and abundance in the South Bay, 1978-1979. U.S. Geological Survey, OpenFile Report 81-132

Hutchinson, A. (1982a). Plankton studies in San Francisco Bay. V. Zooplankton species composition and abundance in the South Bay, 1980-1981. U.S. Geological Survey, Open-File Report 82-1002

Hutchinson, A. (1982b). Plankton studies in San Francisco Bay. VI. Zooplankton species composition and abundance in the North Bay, 1979-1980. U.S. Geological Survey, Open-File Report 82-1003

Joint, I. R., Pomroy, A. J. (1981). Primary production in a turbid estuary. Estuar. coast. Shelf Sci. 13: 303-316

Kirby-Smith, W. (1976). The detritus problem and the feeding and digestion of an estuarine organism. In: Wiley, M. (ed.) Estuarine processes, Vol. 1. Uses, stresses, and adaptation to the estuary. Academic Press, New York, p. 469-479

Malone, T. C. (1977). Environmental regulation of phytoplankton productivity in the lower Hudson Estuary. Estuar. coast. mar. Sci. 5: 157-171

Marra, J. (1978). Phytoplankton photosynthetic response to vertical movement in a mixed layer. Mar. Biol. 46: 203-208

Parsons, T, J., Takahashi, M. (1973). Biological oceanographic processes. Pergamon Press, New York

Patten, B. C. (1968). Mathematical models of plankton production. Int. Revue ges. Hydrobiol. 53: 357-408

Peterson, B. J. (1980). Aquatic primary productivity and the ${ }^{14} \mathrm{C}-\mathrm{CO}_{2}$ method: a history of the productivity problem. Ann. Rev. Ecol. Syst. 11: 359-385

Peterson, D. H., Schemel, L. E., Alpine, A. E., Cole, B. E.,
Hager, S. W., Harmon, D. D., Hutchinson, A., Smith, R. E., Wienke, S. M. (in press). Phytoplankton photosynthesis, nitrogen assimilation and light intensity in a partially mixed estuary. Estuar. coast. Shelf Sci.

Platt, T., Jassby, A. D. (1976). The relationship between photosynthesis and light for natural assemblages of coastal marine phytoplankton. J. Phycol. 12: 421-430

Schindler, D. W. R, Schmidt, R. V., Reid, R. A. (1972). Acidification and bubbling as an alternative to filtration in determining phytoplankton production by the $\mathrm{C}^{14}$ method. J. Fish. Res. Bd Can. 29: 1627-1631

Steemann Nielsen, E., Hansen, V. (1959). Measurements with the carbon-14 technique of the respiration rates in natural populations of phytoplankton. Deep Sea Res. 5: 222-233

Stockner, J. G., Cliff, D. D. (1979). Phytoplankton ecology of Vancouver Harbor. J. Fish. Res. Bd Can. 36: 1-10

Stockner, J. G., Cliff, D. D., Shortreed, K. R. (1979). Phytoplankton ecology of the Strait of Georgia, British Columbia. J. Fish. Res. Bd Can. 36: 657-666

Strickland, J. D. H., Parsons, T. R. (1972). A practical handbook of seawater analysis. Bull. Fish. Res. Bd Can. 167

Sverdrup, H. U. (1953). On conditions for the vernal blooming of phytoplankton. J. Cons. int. Explor. Mer 18: 287-295

Talling, J. F. (1971). The underwater light climate as a controlling factor in the production ecology of freshwater phytoplankton. Mitt. int. Verein. Limnol. 19: 214-243

Thompson, J. K., Nichols, F. H. (1981). Benthic macrofaunal biomass of San Francisco Bay, California: January/February and August 1973. U.S. Geological Survey, Open-File Report 81-1331

Williams, R. B. (1966). Annual phytoplanktonic production in a system of shallow temperate estuaries. In: Barnes, $\mathrm{H}$. (ed.) Some contemporary studies in marine science. Hafner, New York, p. 699-716

Williams, R. B., Murdoch, M. B. (1966). Phytoplankton production and chlorophyll concentration in the Beaufort Channel, North Carolina. Limnol. Oceanogr. 11: 73-82

Wong, R. L. J., Cloern, J. E. (1982). Plankton studies in San Francisco Bay. IV. Phytoplankton abundance and species composition, January 1980-February 1981. U.S. Geological Survey, Open-File Report 82-443 